\title{
Peningkatan Kualitas Kimia Tanah Sulfat Masam dengan Aplikasi Kombinasi Bahan Organik Lokal dan Limbah Agroindustri
}

\section{(Improvement of Chemical Quality Acid Sulphate Soil with Application Local Organic Matter Combined Agroindustrial Wasted)}

\author{
Muhammad Helmy Abdillah*, Dewi Amelia Widiyastuti
}

(Diterima Agustus 2021/Disetujui Januari 2022)

\begin{abstract}
ABSTRAK
Tujuan penelitian ini ialah menilai pengaruh perlakuan kombinasi kompos berbahan organik lokal dan limbah agroindustri pada peningkatan kualitas kimia tanah mineral sulfat masam dan hasil bobot kering akar serta produksi gabah kering giling padi Inpara-3. Penelitian dilaksanakan di rumah kaca Politeknik Hasnur, Kebupaten Barito Kuala, Kalimantan Selatan pada November 2020 sampai Juli 2021 menggunakan desain Rancangan Acak Lengkap pola Tersarang dengan mengaplikasikan 7 perlakuan, yakni, $\mathrm{K}_{0}=$ tanpa kompos dan limbah padat (kontrol); JKD = kombinasi kompos jerami $4 \mathrm{t} \mathrm{ha}^{-1}$ dan dekanter padat $2 \mathrm{t} \mathrm{ha}^{-1}$; JKR $=$ kombinasi kompos jerami $4 \mathrm{t} \mathrm{ha}^{-1}$ dan limbah padat karet remah (LPKR) $2 \mathrm{t} \mathrm{ha}^{-1}$; SKD = kombinasi kompos tandan kosong kelapa sawit (TKKS) $4 \mathrm{t} \mathrm{ha}^{-1}$ dan dekanter padat $2 \mathrm{t} \mathrm{ha}{ }^{-1}$; SKR = kombinasi kompos TKKS $4 \mathrm{t} \mathrm{ha}^{-1}$ dan LPKR $2 \mathrm{t} \mathrm{ha}^{-1} ;$ PKD = kombinasi kompos purun tikus $4 \mathrm{t}$ ha $^{-1}$ dan dekanter padat $2 \mathrm{t} \mathrm{ha}^{-1}$; PKR $=$ kombinasi kompos purun tikus $4 \mathrm{t} \mathrm{ha}^{-1}$ dan LPKR $2 \mathrm{t} \mathrm{ha}^{-1}$. Setiap perlakuan diulang 5 kali sehingga terdapat 35 satuan tanaman percobaan. Hasil penelitian menunjukkan bahwa aplikasi kombinasi kompos jerami padi dan dekanter padat dapat menurunkan Fe- dan Al-terlarut serta meningkatkan ketersediaan fosforus dan kalium. Kombinasi kompos TKKS dan dekanter padat meningkatan pH dan total $\mathrm{N}$-mineral tanah. Kombinasi kompos jerami padi dan limbah padat karet remah mampu meningkatkan bobot kering akar dan bobot gabah kering giling.
\end{abstract}

Kata kunci: kompos; limbah agroindustri; tanah sulfat masam

\section{ABSTRACT}

The purpose of this research was to assess effect of compost treatment from various local organic materials combined with agro-industrial waste to improved chemical quality of acid sulfate mineral soils, to compare of root dry weight and grain weight milled dryness of Inpara-3. This research was conducted at screen house of Polytechnic Hasnur, Barito Kuala District, South Kalimantan from November 2020 to June 2021. This study used Compeletely Randomized Design (CRD) with Tukey's Honestly Significant Difference (HSD) test $\alpha=5 \%$. There were 7 treatments used as, $\mathrm{KO}=$ control. JKD = paddy straw compost $4 \mathrm{t} \mathrm{ha}^{-1}$ and solid decanter $2 \mathrm{t} \mathrm{ha-1}$; JKR = paddy straw compost 4 $t \mathrm{ha}^{-1}$ and solid crumb rubber $2 \mathrm{t} \mathrm{ha-1}$; SKD $=$ empty fruit bunch compost $4 \mathrm{t} \mathrm{ha}^{-1}$ and solid decanter $2 \mathrm{t}$ ha-1; SKR $=$ empty fruit bunch compost $4 \mathrm{t} \mathrm{ha}^{-1}$ and solid crumb rubber $2 \mathrm{t} \mathrm{ha}^{-1}$; PKD = compost of purun tikus (Eleocharis dulcis) $4 \mathrm{t} \mathrm{ha}^{-1}$ and solid decanter $2 \mathrm{t} \mathrm{ha}^{-1}$; PKR = compost of purun tikus $4 \mathrm{t} \mathrm{ha}^{-1}$ and LPKR $2 \mathrm{t} \mathrm{ha}^{-1}$. The treatment was 5 replication so that 35 experimental plant units. The results showed compost paddy straw combinated solid decanter reducing concentration of soluble $\mathrm{Fe}$ and $\mathrm{Al}$ and can increasing availability of $\mathrm{P}$ and $\mathrm{K}$. Treatment of compost empty fruit bunch combinated solid decanter can be increasing $\mathrm{pH}$ and total $\mathrm{N}$-mineral. Compost paddy straw combinated solid crumb rubber gave increasing weight on root dry and grain milled dryness.

Keywords: acid sulfate soil; agroindustrial wasted; compost

\section{PENDAHULUAN}

Lahan pasang surut termasuk dalam lahan marjinal sub-optimal yang berpotensi untuk dikembangkan sebagai lahan pertanian. Luas lahan pasang surut di Indonesia tercatat 20 juta ha, yang terbagi dalam 14 kelompok berdasarkan tipologi (Suwanda \& Noor

Program Studi Budidaya Tanaman Perkebunan, Politeknik Hasnur, Jl. Brigjen H. Hasan Basri, Handil Bakti, Alalak 70582

* Penulis Korespondensi:

Email: abdillah.helmy21@gmail.com
2014). Terdapat 11 juta ha lahan rawa pasang surut yang sebagian besar identik dengan tipologi sulfat masam (Mulyani \& Sarwani 2013). Lahan pasang surut sulfat masam memiliki masalah yang rumit untuk diatasi, khususnya dalam pengelolaan air yang mengakibatkan kemasaman tanah aktual akibat rezim air yang menggenangi dan surut dalam periode tertentu, serta pengolahan tanah yang salah sehingga memengaruhi karakteristik fisiko-kimia dari lahan tersebut.

Menurut catatan nasional, produksi beras di Kalimantan Selatan pada tahun 2018 hingga 2021 menurun dari 1,327 juta ton per tahun menjadi 1,041 juta ton per tahun (BPS 2021), sementara konsumsi 
terus meningkat seiring bertambahnya jumlah penduduk. Produksi beras lokal di provinsi ini akan sulit mencukupi kebutuhan nasional sebab budi daya padi didominasi oleh padi lokal yang hanya satu periode tanam dalam setahun, dengan periode tanam puncak biasanya pada Maret III-April I (Runtunuwu et al. 2012). Hal ini wajar, sebab secara genetik hanya varietas lokal yang mampu bertahan dan tumbuh maksimal di lahan rawa pasang surut sulfat masam, sedangkan varietas unggul belum menunjukkan produksi yang optimal akibat faktor pembatas di lahan tersebut. Oleh karena itu, diperlukan pembenahan tanah mineral sufat masam sehingga varietas unggul baru (VUB) mampu tumbuh optimal, yakni dengan cara membenahi faktor pembatas tersebut. VUB yang relatif bertahan pada karakteristik tanah mineral sulfat masam pasang surut adalah Inpara-3, sebagaimana terlihat dari uji preferensi para petani yang lebih menyukai varietas tersebut dibandingkan VUB lainnya (Koesrini et al. 2020; Rumanti et al. 2020), tetapi produksinya belum optimal sehingga harus didorong dengan aplikasi pupuk anorganik dengan biaya relatif mahal.

Aplikasi bahan organik lokal menjadi satu cara yang sering diterapkan petani di lapangan, tetapi kandungan bahan organik di lahan pasang surut belum mampu mendorong ketersediaan hara karena tidak diperkaya sebelum diaplikasikan. Dalam kajian teoretis, tanah dengan bahan organik di lahan rawa pasang surut sulfat masam dapat dibenahi dengan berbagai perlakuan (Annisa \& Subagio 2016; Masganti et al. 2017). Di antara bahan organik lokal yang potensial kuantitasnya di Kabupaten Barito Kuala adalah jerami padi, tandan kosong kelapa sawit (TKKS), dan purun tikus (Eleocharis dulcis) yang diduga akan lebih bermanfaat apabila diperkaya dalam bentuk kompos dan tambahan bahan komplementer. Hasil penelitian menunjukkan bahwa jerami padi dan gulma lokal di lahan pasang surut yang dikomposkan mampu menurunkan $\mathrm{Fe}^{2+}$ dibandingkan dalam bentuk segar (Annisa \& Subagio 2016), meningkatkan pH tanah dan ketersediaan $\mathrm{P}$, dan menurunkan tingkat keracunan $\mathrm{Al}$ (Susilawati \& Nursyamsi 2013; Masganti et al. 2019; Suriani et al. 2020). Selain itu, kombinasi kompos TKKS dengan berbagai bahan komplementer mampu meningkatkan kapasitas tanah dalam menyediakan unsur hara dan meningkatkan $\mathrm{pH}$ di tanah sulfat masam pasang surut (Andayani \& Hayat 2019; Cahya 2021). Oleh karena itu, pembenah tanah berbahan organik lokal yang dikomposkan berpotensi untuk diaplikasikan, walaupun berbagai penelitian juga melaporkan bahwa aplikasi tersebut belum nyata meningkatkan keharaan tanpa dikombinasikan (Hartatik \& Setyorini 2008; Sugiyanta et al. 2008; Kaparang et al. 2017). Kombinasi dalam aplikasi kompos ditujukan untuk memperkaya kompos sehingga optimal dalam membenahi tanah dan mendorong ketersediaan unsur hara. Kombinasi yang sering diaplikasikan dengan kompos adalah pupuk NPK, yang tidak ekonomis, dan limbah padat ternak yang cukup sulit didapatkan sebab para peternak juga menjualnya. Potensi limbah agroindustri di kabupaten ini cukup tinggi yang berasal dari pabrik pengolahan barang mentah. Limbah ini berpotensi secara kuantitas dan kualitas dalam membenahi tanah, seperti dekanter padat dan limbah padat karet remah (LPKR) (Lubis 2019; Abdillah et al. 2020;) sehingga patut dicoba dan diharapkan dapat meningkatkan produksi tanaman.

Limbah dekanter padat merupakan limbah dari pengolahan crude palm oil (CPO) yang dihasilkan saat pemisahan minyak, cairan, dan padatan oleh mesin dekanter, sedangkan limbah padat dari industri karet remah (LPKR) merupakan limbah hasil pencucian gumpalan lateks yang menyisakan padatan organik yang berasal dari penanganan lateks di kebun. Aplikasi limbah tersebut telah dibuktikan dalam penelitian Lubis (2019), yakni dapat meningkatkan tinggi tanaman, jumlah anakan, jumlah malai, dan produksi gabah tanaman padi. Aplikasi LPKR pada tanah mineral dapat meningkatkat $\mathrm{pH}$ tanah dan C-organik tanah serta ketersedian nitrogen, fosforus, dan kalium (Abdillah \& Aldi 2020). Akan tetapi, hingga saat ini belum ditemukan hasil peningkatan kualitas kimia tanah mineral pasang surut yang ditanami padi berdasarkan aplikasi kombinasi kompos limbah organik lokal dan limbah padat agroindustri. Tujuan penelitian ini ialah menilai pengaruh perlakuan kombinasi kompos berbahan organik lokal dan limbah agroindustri pada peningkatan kualitas kimia tanah mineral sulfat masam, hasil bobot kering akar, serta produksi gabah kering giling padi Inpara-3.

\section{METODE PENELITIAN}

\section{Waktu, Tempat, dan Rancangan Penelitian}

Penelitian ini dilaksanakan di rumah kaca milik Politeknik Hasnur, Kebupaten Barito Kuala, Kalimantan Selatan, pada November 2020 sampai Juli 2021. Kegiatan ini merupakan percobaan pendahuluan yang menggunakan ember berkapasitas $28 \mathrm{~L}$ sebagai wadah menanam padi. Desain Rancangan Acak Lengkap (RAL) pola Tersarang diterapkan dengan mengaplikasikan 7 perlakuan, yakni $\mathrm{K}_{0}=$ tanpa kompos dan limbah padat (kontrol); JKD = kombinasi kompos jerami $4 \mathrm{t} \mathrm{ha}^{-1}$ dan dekanter padat $2 \mathrm{t} \mathrm{ha}^{-1}$; JKR = kombinasi kompos jerami $4 \mathrm{t} \mathrm{ha}^{-1}$ dan limbah padat karet remah (LPKR) 2 t.ha $^{-1}$; SKD = kombinasi kompos TKKS $4 \mathrm{t} \mathrm{ha}^{-1}$ dan dekanter padat $2 \mathrm{t} \mathrm{ha}^{-1}$; SKR = kombinasi kompos TKKS $4 \mathrm{t} \mathrm{ha}^{-1}$ dan LPKR $2 \mathrm{t} \mathrm{ha}^{-1}$; $\mathrm{PKD}=$ kombinasi kompos purun tikus $4 \mathrm{t} \mathrm{ha}^{-1}$ dan dekanter padat $2 \mathrm{t} \mathrm{ha}^{-1}$; PKR $=$ kombinasi kompos purun tikus $4 \mathrm{t} \mathrm{ha}^{-1}$ dan LPKR $2 \mathrm{t} \mathrm{ha}^{-1}$. Setiap perlakuan diulang 5 kali sehingga terdapat 35 satuan tanaman percobaan.

\section{Persiapan Bahan dan Media Tanam}

Keperluan bahan organik sebagai perlakuan dikonversikan ke dalam satuan gram karena percobaan ini dilakukan di dalam ember sebagai wadah. 
Percobaan diawali dengan membuat kompos TKKS (Abdillah 2021), mencacah seluruh bagian tumbuhan purun tikus dan jerami padi, masing-masing $10 \mathrm{~kg}$, kemudian mengomposkannya selama 60 hari dengan mengaplikasikan pupuk organik cair yang berasal dari sisa sayuran, cacahan keong mas, dan leri, sesuai dengan cara Abdillah (2021). Dari setiap bahan kompos tersebut diambil 1,3 kg untuk dikombinasikan dengan dekanter padat dari PT $X$ dan LPKR yang didapat dari PT Y yang kemudian diaplikasikan sesuai dengan desain perlakuan. Tanah yang digunakan sebagai media tanam adalah tanah yang diambil dari lahan sawah bukaan baru di lahan pasang surut zona luapan air tipe B dari Desa Sungai Lumbah Kecamatan Alalak. Bahan tanam yang digunakan adalah benih Inpara-3 yang berumur 127 hari agar hasil penelitian lebih aplikatif dengan perspektif petani lokal. Padi ditanam di dalam ember berkapasitas $28 \mathrm{~L}$ yang digenangi air setinggi $4 \mathrm{~cm}$ dari permukaan tanah selama 96 jam dan dikeringkan akibat evapotranspirasi selama 72 jam dalam satu pekan; hal ini dijalankan hingga 15 hari sebelum tanaman dipanen. Kondisi ini diasumsikan seperti pengaruh kenaikan dan penurunan muka air pada agrohidrologi lahan pasang surut.

\section{Variabel Pengamatan}

Peubah yang diamati dibagi menjadi dua kelompok peubah pengamatan, yakni (1) kelompok peubah tanah dan (2) kelompok peubah tanaman.

Sampel tanah diambil 30 hari sebelum tanaman dipanen, diasumsikan agar tanah yang diambil menggambarkan kondisi kimia tanah yang memengaruhi pertumbuhan dan produksi tanaman. Peubah yang dianalisis ialah Fe-terlarut, dianalisis dengan metode spektrofotometer pada panjang gelombang $(\lambda) 508 \mathrm{~nm}$, menggunakan pengompleks o-fenantrolin dan pereduksi hidroksilamina hidroksida, Al-terlarut dianalisis dengan metode titrasi $\mathrm{KCl}, \mathrm{pH}$-tanah dengan pelarut $\mathrm{H}_{2} \mathrm{O}$, total $\mathrm{N}$-mineral menggunakan metode spektrofotometer dengan menganalisis $\mathrm{N}-\mathrm{NH}_{4}{ }^{+}$pada $\lambda$ $647 \mathrm{~nm}$ dan $\mathrm{N}^{-\mathrm{NO}_{3}}{ }^{-}$pada $\lambda 640 \mathrm{~nm}$ dengan ekstraksi $\mathrm{KCl} 1 \mathrm{~N}$ kemudian hasilnya dijumlahkan untuk mendapatkan total $\mathrm{N}$-mineral, P-tersedia dianalisis menggunakan metode Bray-II dengan pengestraksi $\mathrm{NH}_{4} \mathrm{~F}$ dan $\mathrm{HCl}$ dan diukur pada $\lambda 660 \mathrm{~nm}$, dan $\mathrm{K}$ dapatdipertukarkan dianalisis menggunakan metode fotometer nyala dengan ekstraksi amonium asetat $\left(\mathrm{NH}_{4} \mathrm{OAc}\right) 1 \mathrm{NpH}$ 7.0.

Sampel tanaman diambil setelah panen. Ada 2 peubah yang diukur, yakni bobot kering akar diukur dengan mengeringkan akar dalam oven selama 72 jam pada suhu $70^{\circ} \mathrm{C}$, dan bobot gabah kering giling (GKG) yang dihitung dengan cara mengeringkan gabah yang telah dipetik dari malai kemudian dijemur di bawah sinar matahari selama 10 jam (sesuai dengan kebiasaan petani lokal).

\section{Analisis Data}

Data penelitian diuji normalitasnya menggunakan model Kolmogrov-Smirnov dan uji homogenitas menggunakan model Barlett. Jika data dinyatakan normal dan homogen, maka uji dilanjutkan dengan analisis keragaman guna menguji nilai perbedaan antarperlakuan. Apabila terdapat perbedaan nyata antarperlakuan, maka dilanjutkan uji beda nilai tengah dengan model beda nyata jujur pada taraf $\alpha=5 \%$ untuk membandingkan pengaruh perlakuan yang berbeda nilai tengahnya. Semua uji tersebut menggunakan aplikasi SPSS 25.

\section{HASIL DAN PEMBAHASAN}

\section{Fe-terlarut}

Konsentrasi $\mathrm{Fe}$ diukur dengan menganalisis $\mathrm{Fe}^{2+}$ dan $\mathrm{Fe}^{3+}$ yang tereduksi menjadi $\mathrm{Fe}^{2+}$. Gambar 1 menunjukkan bahwa perlakuan kombinasi kompos

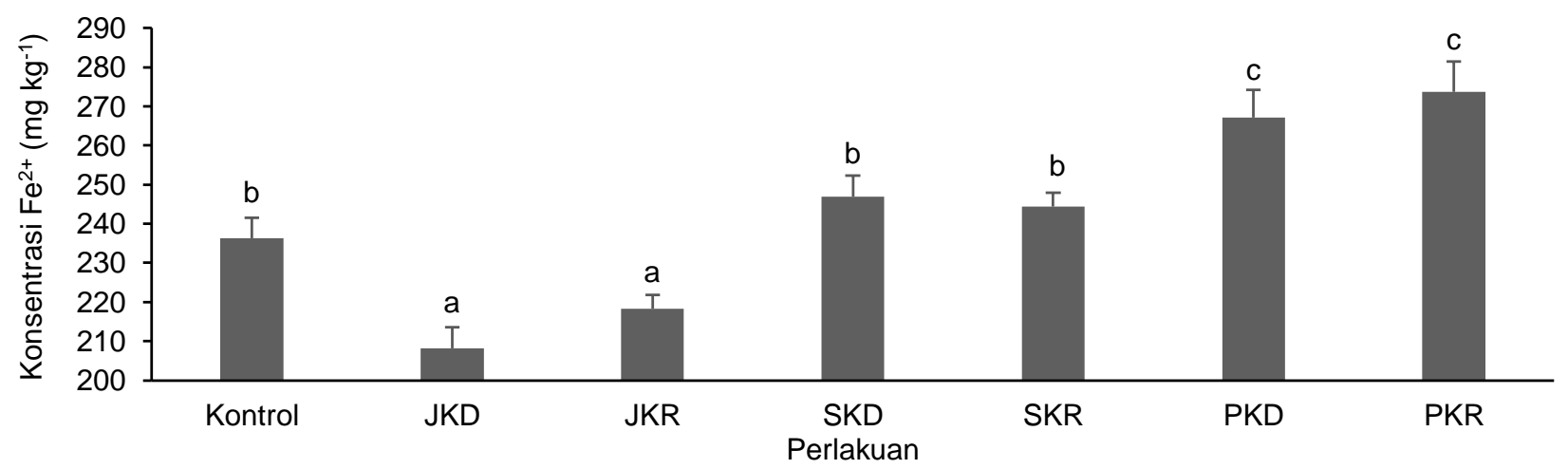

Gambar 1 Konsentrasi $\mathrm{Fe}^{2+}$ pada tanah mineral pasang surut, baik tanpa maupun dengan aplikasi kompos dari berbagai bahan organik lokal yang dikombinasikan. Garis di atas batang menunjukkan simpangan baku $(n=5)$. Huruf yang sama di atas garis pada setiap perlakuan menunjukkan tidak berbeda nyata berdasarkan BNJ taraf $\alpha=$ $5 \%$. Kontrol = tanpa kompos dan komplementer; JKD = kombinasi kompos jerami $4 \mathrm{t} \mathrm{ha} \mathrm{A}^{-1}$ dan dekanter padat 2 $\mathrm{t}$ ha-1; JKR = kombinasi kompos jerami $4 \mathrm{t} \mathrm{ha}^{-1}$ dan limbah padat karet remah $2 \mathrm{t} \mathrm{ha}^{-1}$; SKD = kombinasi kompos TKKS $4 \mathrm{t} \mathrm{ha}^{-1}$ dan dekanter padat $2 \mathrm{t} \mathrm{ha-1}$; SKR $=$ kombinasi kompos TKKS $4 \mathrm{t}^{-1} \mathrm{a}^{-1}$ dan limbah padat karet remah $2 \mathrm{t} \mathrm{ha-1} ; \mathrm{PKD}=$ kombinasi kompos purun tikus $4 \mathrm{t} \mathrm{ha}^{-1}$ dan dekanter padat $2 \mathrm{t} \mathrm{ha}^{-1}$; PKR $=$ kombinasi kompos purun tikus $4 \mathrm{t}$ ha-1 dan limbah padat karet remah $2 \mathrm{t}$ ha-1. 
jerami padi dan dekanter padat (JKD) menghasilkan konsentrasi $\mathrm{Fe}$ terendah dibandingkan perlakuan lain, tetapi tidak berbeda nyata dibandingkan kombinasi kompos jerami dan LPKR yang dapat menurunkan konsentrasi Fe-terlarut dari 236,2 $\mathrm{mg} \mathrm{kg}^{-1}$ pada perlakuan kontrol menjadi masing-masing $208,2 \mathrm{mg}$ $\mathrm{kg}^{-1}$ dan $216,7 \mathrm{mg} \mathrm{kg}^{-1}$. Hal ini menunjukkan bahwa konsentrasi Fe-terlarut dapat ditekan dengan aplikasi kombinasi kompos jerami dan limbah agroindustri dibandingkan dengan kontrol. Aplikasi kombinasi kompos purun tikus dan limbah agroindustri (PKD dan PKR) menunjukkan konsentrasi Fe-terlarut yang sangat tinggi, yakni masing-masing $267,2 \mathrm{mg} \mathrm{kg}^{-1}$ dan $273,8 \mathrm{mg} \mathrm{kg}^{-1}$. Mungkin hal ini karena purun tikus merupakan tanaman hiperkumulator logam besi dan aluminium di lahan rawa (Annisa et al. 2011; Maimunah 2019).

Kompos jerami padi terbukti mampu mengkelat logam di dalam tanah, mungkin karena proses degradasi bahan jerami padi lebih cepat dibandingkan bahan lain yang lebih keras sehingga mampu lebih cepat menghasilkan asam organik sederhana. Hal ini sejalan dengan penelitian terdahulu (Hairani \& Susilawati 2013; Ifansyah \& Saidy 2019) yang melaporkan penurunan nyata kelarutan Fe setelah aplikasi kompos jerami padi. Suriani et al. (2020) menyatakan bahwa aplikasi kompos jerami dapat meningkatkan $\mathrm{pH}$ tanah dan menurunkan konsentrasi Fe.

Daya serap dan simpan air pada penggenangan dan pengeringan tanah menjadi faktor penentu aktivitas Fe yang berhubungan dengan kondisi redoks, $\mathrm{pH}$ tanah, jenis mineral, dekomposisi bahan organik, dan aktivitas mikroorganisme (Susilawati \& Fahmi 2013). Pada percobaan ini, kondisi mikrohidrologi diatur dengan penggenangan selama 96 jam dan dibiarkan mengering sendiri (evapotranspirasi) dalam rentang waktu 72 jam setelah penggenangan, sehingga logam tidak tercuci (terlindi) dan terjadi oksidasi. Kemungkinan ini adalah salah satu penyebab nilai Fe-terlarut yang fluktuatif. Selain itu, diduga penurunan konsentrasi Fe terjadi karena interaksi dan pengaruh dekanter padat dan LPKR yang memiliki rata-rata $\mathrm{pH}$ mendekati netral dan mengandung $\mathrm{C}$ organik yang cukup tinggi (Abdillah et al. 2020; Duaja et al. 2020; Sarman et al. 2021).

\section{Al-terlarut}

Aplikasi berbagai kombinasi kompos dan dekanter padat maupun LPKR dapat menurunkan konsentrasi Al-terlarut pada tanah mineral pasang surut (Gambar 2). Terdapat perbedaan nyata antara perlakuan kompos dari bahan organik jerami padi, TKKS, dan purun tikus yang masing-masing dikombinasikan dekanter padat maupun LPKR dibandingkan perlakuan kontrol, walaupun dalam pengharkatan kriteria tanah, nilai Al-terlarut masih termasuk kategori tinggi. Rahmadi (2021) berpendapat bahwa nilai rata-rata konsentrasi Al-dapat-tukar pada semua tipe luapan di tanah mineral pasang surut di beberapa wilayah Kabupaten Barito Kuala ialah 6,03 me $100^{-1}$. Kondisi ini adalah akibat $\mathrm{Al}$ yang terhidrolisis menghasilkan $\mathrm{H}^{+}$ yang diilustrasikan sebagai berikut: $\mathrm{Al}^{3+}+\mathrm{H}_{2} \mathrm{O} \rightleftharpoons$ $\mathrm{Al}(\mathrm{OH})_{3}+3 \mathrm{H}^{+}$sehingga memperparah kemasaman tanah (Druchok et al. 2004; Hartatik et al. 2006).

Aplikasi bahan organik khususnya jerami padi dapat memfiksasi Al dan mengurangi terbentuknya $\mathrm{H}^{+}$ sehingga tidak mengkelat unsur hara. Hal ini sejalan dengan pendapat Susilawati \& Nursyamsi (2013), bahwa aplikasi jerami padi berperan penting dalam meningkatkan produktivitas sulfat masam karena dapat menjadi sumber hara tanaman sekaligus menghasilkan asam organik sebagai pengkelat logam Al yang sangat berkaitan erat dengan oksidasi pirit yang menghasilkan $\mathrm{SO}_{4}$. Penelitian Ifansyah \& Saidy (2019) mengemukakan bahwa kandungan Al-terlarut akibat aplikasi kompos jerami padi pada sistem SRI di lahan pasang surut lebih rendah dibandingkan dengan sistem pertanaman konvensional.

\section{Derajat Kemasaman Tanah}

Aplikasi kombinasi kompos dan dekanter padat maupun LPKR dapat meningkatkan $\mathrm{pH}$ tanah diban-

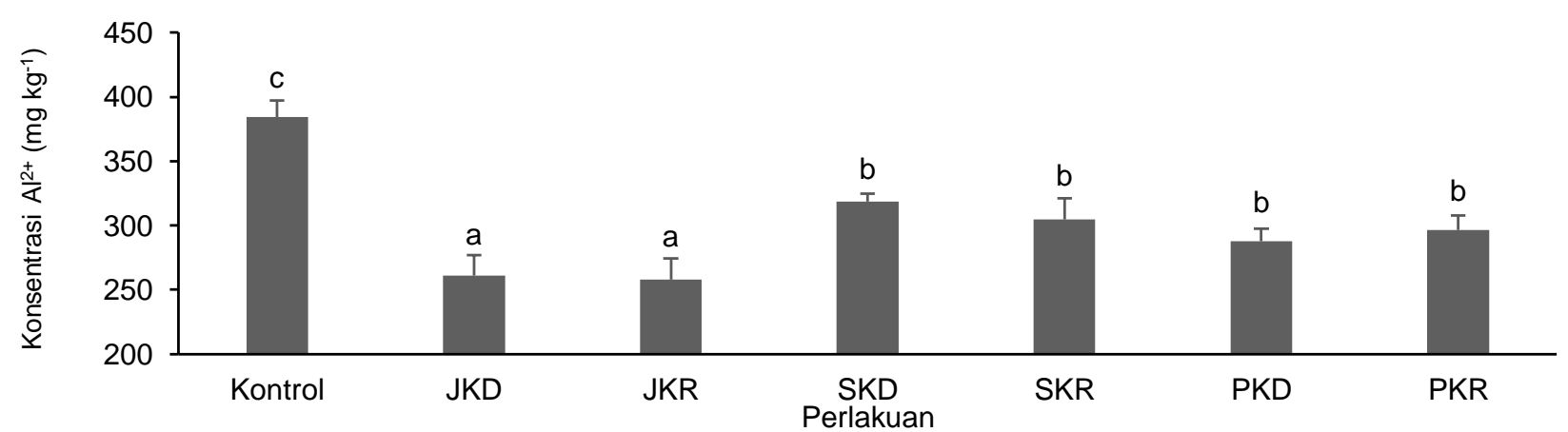

Gambar 2 Konsentrasi $\mathrm{Al}^{2+}$ pada tanah mineral pasang surut, baik tanpa maupun dengan aplikasi kompos dari berbagai bahan organik lokal yang dikombinasikan. Garis di atas batang menunjukkan simpangan baku $(n=5)$. Huruf yang sama di atas garis pada setiap perlakuan menunjukkan tidak berbeda nyata berdasarkan BNJ $\operatorname{taraf} \alpha=5 \%$. Kontrol = tanpa kompos dan komplementer; JKD = kombinasi kompos jerami $4 \mathrm{t} \mathrm{ha}{ }^{-1}$ dan dekanter padat $2 \mathrm{t}$ ha ${ }^{1}$; JKR $=$ kombinasi kompos jerami $4 \mathrm{t} \mathrm{ha}^{-1}$ dan limbah padat karet remah $2 \mathrm{t} \mathrm{ha}{ }^{-1}$; SKD = kombinasi kompos TKKS $4 \mathrm{t} \mathrm{ha}^{-1}$ dan dekanter padat $2 \mathrm{t}$ ha-1; SKR $=$ kombinasi kompos TKKS $4 \mathrm{t} \mathrm{ha}^{-1}$ dan limbah padat karet remah $2 \mathrm{t}$ ha ${ }^{1}$; PKD = kombinasi kompos purun tikus $4 \mathrm{t} \mathrm{ha}^{-1}$ dan dekanter padat $2 \mathrm{t} \mathrm{ha-1}$; PKR $=$ kombinasi kompos purun tikus $4 \mathrm{t} \mathrm{ha-1}$ dan limbah padat karet remah $2 \mathrm{t} \mathrm{ha}^{-1}$. 
dingkan perlakuan kontrol kecuali perlakuan kombinasi kompos purun tikus dan dekanter padat yang tidak berbeda nyata dengan kontrol (Gambar 3). Aplikasi kombinasi kompos TKKS dan dekanter padat (SKD) menunjukkan $\mathrm{pH}$ tertinggi, yakni 4,46, dan $\mathrm{pH}$ terendah pada perlakuan kontrol $(3,93)$. Boleh jadi, ini karena pengaruh dekanter padat yang mampu menjadi bufer $\mathrm{pH}$ tanah meskipun pada perlakuan ini terlihat konsentrasi logam yang cukup tinggi. Metode analisis $\mathrm{Fe}$ dan $\mathrm{Al}$ membuat terindikasinya bentuk trivalensi yang dikonversi $\mathrm{ke} \mathrm{Fe}^{2+}$ dan $\mathrm{Al}^{2+}$ sehingga hasil analisis tanah menunjukkan nilai yang tinggi.

Putri (2021) mendapati bahwa aplikasi kompos TKKS pada tanah mineral pasang surut ternyata memengaruhi kenaikan $\mathrm{pH}$ tanah dan meningkatkan konsentrasi Fe. Diduga, kelarutan Fe terkelat pada kompleks ligan asam organik (Rahman et al. 2021) yang terbentuk seiring dengan berjalannya dekomposisi TKKS yang cukup lambat di dalam tanah membentuk $\mathrm{Fe}^{3+}$ berdampak pada penurunan $\mathrm{pH}$ tanah.
Ligan organik yang masih cukup tinggi pada kompos TKKS, berupa lignin, dapat teroksidasi menjadi oksalat, asetat, dan sitrat (Ibrahim et al. 2019; Sari et al. 2021; Torres et al. 2021). Proses ini mendorong kristalisasi oksida $\mathrm{Fe}$ sehingga menurunkan aktivasi $\mathrm{H}^{+}$. Annisa \& Hanudin (2013) menyatakan urutan yang menghambat laju pembentukan oksida besi $\mathrm{Fe}(\mathrm{II})$, yakni oksalat $>$ asetat $>$ tartat $>$ sitrat.

\section{Total N-Mineral Tanah}

Gambar 4 menunjukkan perbedaan nyata antara aplikasi kombinasi kompos-limbah agroindustri dan kontrol dari segi peningkatan konsentrasi $\mathrm{N}$-mineral tanah. Kombinasi kompos TKKS dan LPKR (SKR) maupun dekanter padat (SKD) terbukti mampu meningkatkan total $\mathrm{N}$-mineral pada tanah mineral pasang surut, yakni masing-masing $97,10 \mathrm{mg} \mathrm{kg}^{-1}$ dan $96,82 \mathrm{mg} \mathrm{kg}^{-1}$.

Aplikasi kompos dapat memengaruhi mineralisasi nitrogen dari $\mathrm{N}$-organik menjadi $\mathrm{N}$-anorganik pada

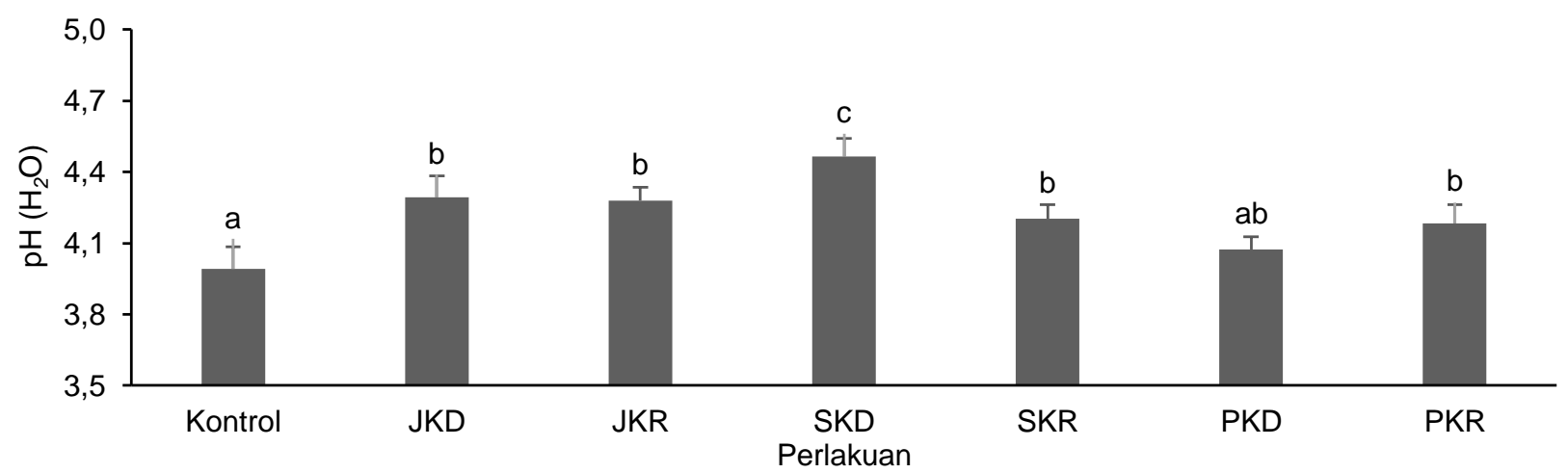

Gambar 3 Keasaman $(\mathrm{pH})$ tanah mineral pasang surut, baik tanpa maupun dengan aplikasi kompos dari berbagai bahan organik lokal yang dikombinasikan. Garis di atas batang menunjukkan simpangan baku $(\mathrm{n}=5)$. Huruf yang sama di atas garis pada setiap perlakuan menunjukkan tidak berbeda nyata berdasarkan BNJ taraf $\alpha=5 \%$. Kontrol $=$ tanpa kompos dan komplementer; JKD = kombinasi kompos jerami $4 \mathrm{t} \mathrm{ha}^{-1}$ dan dekanter padat $2 \mathrm{t} \mathrm{ha-1}$; JKR $=$ kombinasi kompos jerami $4 \mathrm{t}$ ha-1 dan limbah padat karet remah $2 \mathrm{t} \mathrm{ha-1}$; SKD = kombinasi kompos TKKS $4 \mathrm{t}$ ha

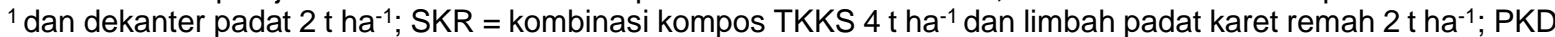
$=$ kombinasi kompos purun tikus $4 \mathrm{t} \mathrm{ha}^{-1}$ dan dekanter padat $2 \mathrm{t} \mathrm{ha}^{-1} ; \mathrm{PKR}=$ kombinasi kompos purun tikus $4 \mathrm{t}$ ha ${ }^{1}$ dan limbah padat karet remah $2 \mathrm{t} \mathrm{ha-1}$.

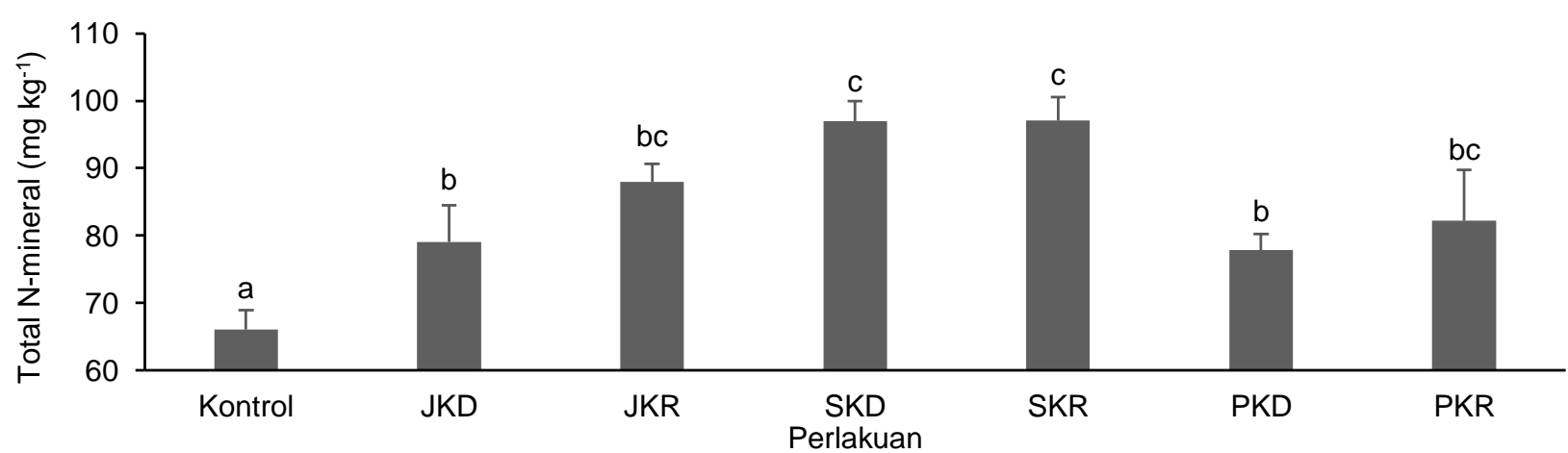

Gambar 4 Total N-mineralisasi pada tanah mineral pasang surut, baik tanpa maupun dengan aplikasi kompos dari berbagai bahan organik lokal yang dikombinasikan. Garis di atas batang menunjukkan simpangan baku $(n=5)$. Huruf yang sama di atas garis pada setiap perlakuan menunjukkan tidak berbeda nyata berdasarkan BNJ taraf $\alpha=5 \%$. Kontrol = tanpa kompos dan komplementer; JKD = kombinasi kompos jerami $4 \mathrm{t} \mathrm{ha}^{-1}$ dan dekanter padat $2 \mathrm{t}$ ha ${ }^{1}$; JKR = kombinasi kompos jerami $4 \mathrm{t} \mathrm{ha}^{-1}$ dan limbah padat karet remah $2 \mathrm{t} \mathrm{ha}{ }^{-1}$; SKD = kombinasi kompos TKKS $4 \mathrm{t} \mathrm{ha}^{-1}$ dan dekanter padat $2 \mathrm{t} \mathrm{ha}{ }^{-1}$; SKR $=$ kombinasi kompos TKKS $4 \mathrm{t} \mathrm{ha}^{-1}$ dan limbah padat karet remah $2 \mathrm{t}$ ha1; PKD = kombinasi kompos purun tikus $4 \mathrm{t} \mathrm{ha}^{-1}$ dan dekanter padat $2 \mathrm{t} \mathrm{ha} \mathrm{a}^{-1}$; $\mathrm{PKR}=$ kombinasi kompos purun tikus $4 \mathrm{t} \mathrm{ha}{ }^{-1}$ dan limbah padat karet remah $2 \mathrm{t} \mathrm{ha}^{-1}$. 
tanah tergenang. Proses mineralisasi pada tanah mineral tergenang sangat bergantung pada bahan dan kuantitas bahan organik yang digunakan serta kondisi genangan air yang pada akhirnya memengaruhi kondisi aerob maupun anaerob dalam proses tersebut. Anggria et al. (2014) mengaplikasikan 20 t ha $^{-1}$ kompos jerami padi dan terbukti meningkatkan transformasi $\mathrm{N}$ mineral tanah tergenang. Namun, semakin lama pembenaman kompos di dalam tanah dengan penggenangan air, justru semakin rendah $\mathrm{N}$-mineral.

Perlakuan kombinasi kompos dari berbagai jenis bahan dan limbah agroindustri terlihat berpengaruh dibandingkan dengan kontrol, tetapi kombinasi kompos TKKS dan limbah agroindustri ternyata menghasilkan konsentarsi total N-mineral tertinggi. Diduga kapasitas air pada perlakuan SKD lebih basah yang terlihat secara fisik di lapangan dibandingkan perlakuan lain, terutama kontrol, menyebabkan $\mathrm{N}-\mathrm{NH}_{4}{ }^{+}$lebih dominan sehingga total N-mineral pada perlakuan tersebut lebih tinggi. Secara fisik, daya serap air pada TKKS lebih tinggi dan daya simpannya pun lebih lama (Tao et al. 2018; Zaharah \& Lim 2000) sehingga hal ini yang membentuk dominasi $\mathrm{NH}_{4}{ }^{+}$. Selain itu, mungkin juga karena kandungan hara dekanter padat yang dapat berinteraksi positif dengan kompos TKKS. Hal ini didukung oleh temuan Indriyati et al. (2008), bahwa aplikasi bahan organik yang belum terdekomposisi dengan matang pada tanah tergenang membentuk $\mathrm{N}$ $\mathrm{NH}_{4}{ }^{+}$lebih tinggi dibandingkan dengan yang telah terombak sempurna; hal ini yang menyebabkan total $\mathrm{N}$ mineral pada perlakuan SKR maupun SKD cenderung lebih tinggi dibandingkan perlakuan lain. Abdillah (2021) berpendapat bahwa nisbah C/N kompos TKKS yang digunakan dalam penelitian ini adalah 21,8 , yang artinya tergolong cukup tinggi, sehingga berpotensi masih terjadi perombakan pada saat diaplikasikan ke tanah. Proses mineralisasi juga didukung oleh $\mathrm{pH}$ tanah dan proses ini dilakukan oleh mikroorganisme asidifilik. Selain itu, mineralisasi juga dikendalikan oleh keberadaan oksida besi dan aluminium dalam tanah (Septiana et al. 2019). Winarni et al. (2015) menjelaskan bahwa pupuk hijau dari lamtoro dengan nisbah $\mathrm{C} / \mathrm{N} \quad 16,03$ mengalami pola kenaikan mineralisasi yang lambat dibandingkan pupuk hijau lainya. Meskipun demikian, persentase $\mathrm{N}$-total dan $\mathrm{N}$ tersedia justru tertinggi, dengan nilai masing-masing 0,250\% dan 152,29 ppm setelah pekan ke-12 masa inkubasi dalam tanah sawah. Sebabnya ialah masih terjadi perombakan hingga nisbah $\mathrm{C} / \mathrm{N}$ mencapai titik minimum.

\section{P-tersedia Tanah}

Konsentarsi $\mathrm{P}$ tertinggi dengan indeks $5,96 \mathrm{mg} \mathrm{kg}^{-1}$ pada perlakuan kombinasi kompos jerami padi dan dekanter padat (JKD) berbeda nyata dibandingkan perlakuan lainnya (Gambar 5). Perlakuan tersebut dapat membebaskan $P$ dari jerapan logam Fe dan Al, seperti juga terlihat dari konsentrasi $\mathrm{Fe}$ dan $\mathrm{Al}$ yang turun pada perlakuan JKD dan JKR. Hairani \& Susilawati (2013) mendapati kenaikan P setelah aplikasi kompos jerami padi. Selain itu, peningkatan $P$ juga dapat disebabkan oleh interaksi antara keharaan kombinasi kompos jerami dan dekanter padat, sedangkan pada kombinasi kompos TKKS dan purun tikus bisa saja terjadi interaksi tetapi belum signifikan seperti halnya JKD yang mungkin disebabkan sifat bahan kompos yang rendah unsur $\mathrm{P}$ maupun $\mathrm{P}$ terfiksasi oleh logam.

Penelitian Putri (2021) menunjukkan bahwa aplikasi kompos TKKS sebanyak $5 \mathrm{t} \mathrm{ha}^{-1}$ ke tanah mineral pasang surut hanya mampu meningkatkan P-tersedia sebesar 13,3 $\mathrm{mg} \mathrm{kg}^{-1}$ dari perlakuan kontrol $(7,1 \mathrm{mg} \mathrm{kg}$ ${ }^{1}$ ), tetapi pada akhirnya semakin tinggi dosis TKKS semakin rendah ketersediaan $\mathrm{P}$, akibat kandungan $\mathrm{Fe}$ pada TKKS cukup tinggi. Pada perlakuan kombinasi kompos purun tikus dan dekanter padat maupun LPKR

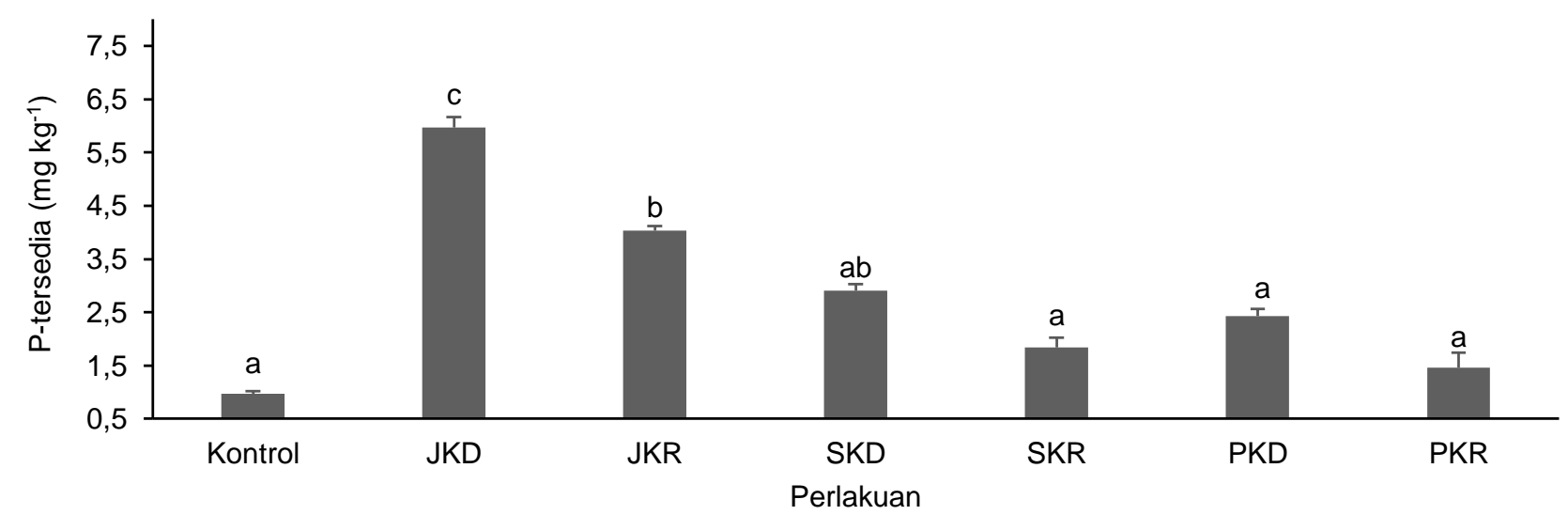

Gambar 5 Konsentrasi P-tersedia pada tanah mineral pasang surut, baik tanpa maupun dengan aplikasi kompos dari berbagai bahan organik lokal yang dikombinasikan. Garis di atas batang menunjukkan simpangan baku $(n=5)$. Huruf yang sama di atas garis pada setiap perlakuan menunjukkan tidak berbeda nyata berdasarkan BNJ taraf $\alpha=5 \%$. Kontrol = tanpa kompos dan komplementer; JKD = kombinasi kompos jerami $4 \mathrm{t} \mathrm{ha}^{-1}$ dan dekanter padat $2 \mathrm{t} \mathrm{ha}^{-1} ; \mathrm{JKR}=$ kombinasi kompos jerami $4 \mathrm{tha}^{-1}$ dan limbah padat karet remah $2 \mathrm{t} \mathrm{ha}^{-1}$; SKD = kombinasi kompos TKKS 4 t ha-1 dan dekanter padat $2 \mathrm{t}$ ha-1; SKR $=$ kombinasi kompos TKKS 4 t ha-1 dan limbah padat karet remah $2 \mathrm{t} \mathrm{ha-1}$; PKD = kombinasi kompos purun tikus $4 \mathrm{t} \mathrm{ha}^{-1}$ dan dekanter padat $2 \mathrm{t} \mathrm{ha}^{-1}$; $\mathrm{PKR}=$ kombinasi kompos purun tikus $4 \mathrm{t} \mathrm{ha}^{-1}$ dan limbah padat karet remah $2 \mathrm{t} \mathrm{ha-1}$. 
terlihat konsentrasi $\mathrm{P}$-tersedia sangat rendah karena tingginya kandungan unsur logam Fe dan Al sehingga potensial P-tersedia di dalam tanah maupun dari limbah agroindustri justru semakin terfiksasi. Hal ini didukung oleh laporan Asikin \& Thamrin (2012); Napisah \& Annisa (2019), bahwa tumbuhan liar purun tikus merupakan tumbuhan yang mampu mengakumulasi logam dalam tubuhnya selama siklus hidupnya sehingga ketika tumbuhan tersebut diaplikasikan ke tanah, justru logam yang terakumulasi tersebut berpotensi terurai kembali ke tanah dan akhirnya mengkelat $P$ yang ada.

Konsentrasi $P$ yang rendah juga disebabkan oleh $P$ tersedia di tanah sulfat masam dari lahan pasang surut juga sangat rendah akibat $\mathrm{pH}$ dan kelarutan logam. Rahmadi (2021) menerangkan bahwa ketersediaan $P$ pada tanah mineral sulfat masam di lahan pasang surut di beberapa daerah di Kabupaten Barito Kuala memang tergolong rendah dengan rata-rata $4,56 \mathrm{mg}$ $\mathrm{kg}^{-1}$ pada semua tipe luapan. Meskipun kompos dengan kombinasinya telah diaplikasikan, tetap saja tidak meningkatkan ketersediaan $\mathrm{P}$ secara nyata, sebab degradasi bahan organik belum sempurna sehingga justru menurunkan ketersediaan $P$. Jadi, tanah tetap dalam harkat yang masam dan kondisi Fedan Al-terlarut tetap tinggi. Fahmi et al. (2009) juga menyatakan bahwa nisbah $\mathrm{C} / \mathrm{N}$ yang masih tinggi dapat menurunkan kelarutan $\mathrm{P}$ dan $\mathrm{pH}$ tanah serta meningkatkan mobilisasi Fe-terlarut.

\section{Kalium dapat-dipertukarkan}

Perlakuan kontrol berbeda nyata dibandingkan dengan perlakuan aplikasi berbagai kombinasi kompos dan dekanter padat maupun LPKR, kecuali pada perlakuan kombinasi kompos purun tikus dan dekanter padat (PKD) (Gambar 6). Unsur hara K cukup sulit tersedia pada tanah mineral pasang surut, sebab sifatnya mudah tercuci dan terikat kuat pada mineral liat (Al-jabri 2013; Sardans \& Peñuelas 2015). Namun, aplikasi bahan organik mampu menyediakan $\mathrm{K}$ meskipun dalam pengharkatan masih tergolong rendah hingga sedang.

Aplikasi kombinasi kompos jerami dan dekanter padat (JKD) maupun LKPR (JKR) dapat meningkatkan konsentrasi $\mathrm{K}$, masing-masing 0,37 me $\mathrm{kg}^{-1}$ dan 0,35 me $\mathrm{kg}^{-1}$ dibandingkan perlakuan lain. Kandungan $\mathrm{K}$ pada jerami padi memang lebih tinggi dibandingkan pada bahan kompos lain. Selain itu, mungkin ada interaksi antara kompos dan dekanter padat maupun LPKR yang telah mengandung unsur hara maupun mikroorganisme penyedia $\mathrm{K}$. Hal ini sejalan dengan temuan Razie et al. (2013), bahwa aplikasi jerami padi yang diperkaya mampu meningkatkan unsur $\mathrm{K}$ tanah serta serapan tanaman padi dengan model budi daya SRI di lahan pasang surut. Selain itu, Barus (2011) melaporkan bahwa aplikasi jerami padi ke tanah mineral pasang surut mampu meningkatkan $\mathrm{K}$ sebab kandungan unsur K-total pada bahan tersebut cukup tinggi, yakni $0,79 \%$.

\section{Bobot Kering Akar}

Gambar 7 menunjukkan peningkatan bobot kering akar tanaman padi yang ditanam pada perlakuan berbagai kombinasi kompos dan dekanter padat maupun LPKR dibandingkan perlakuan kontrol. Bobot kering akar terendah dihasilkan oleh perlakuan kontrol dengan rerata $4,21 \mathrm{~g}$, sedangkan bobot kering akar tertinggi dihasilkan oleh kombinasi kompos jerami dan LPKR (JKR), yakni 14,91 g. Namun, keadaan ini tidak berbeda nyata dibandingkan perlakuan kombinasi kompos TKKS dan LPKR (SKR), yakni 14,64 g, sedangkan perlakuan JKD, SKD, PKD, serta PKR tidak berbeda nyata berdasarkan uji BNJ taraf $\alpha 5 \%$.

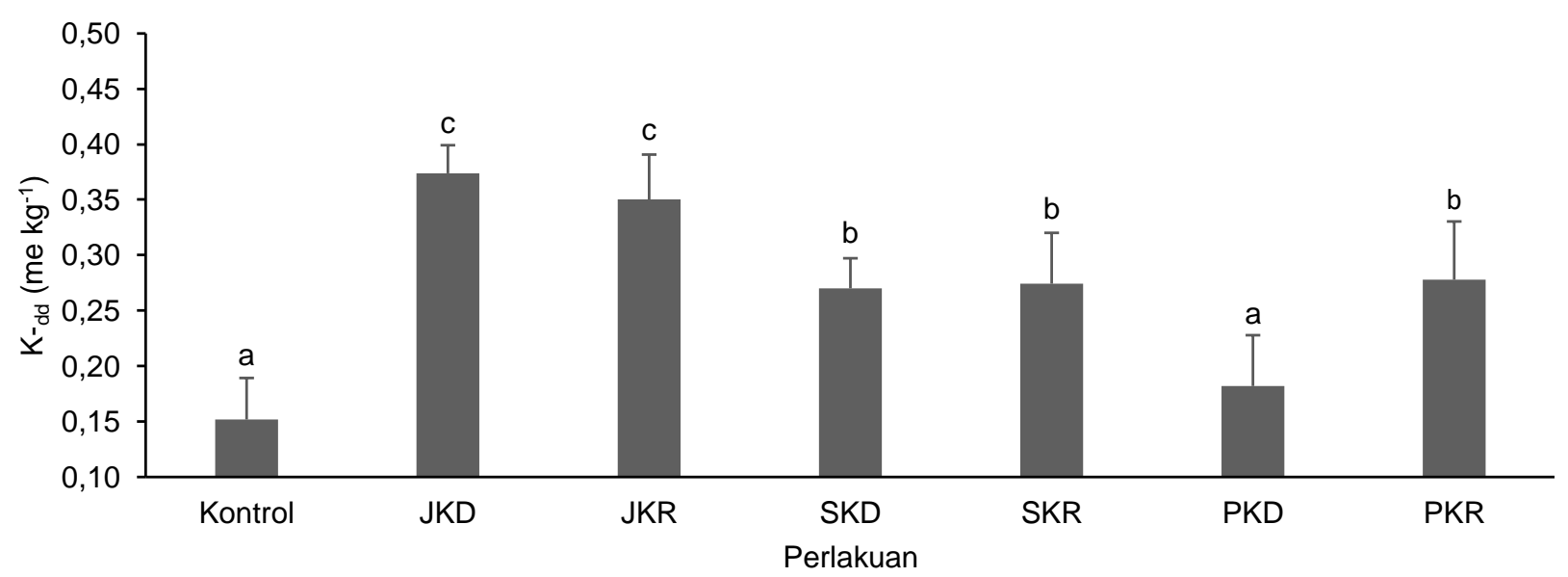

Gambar 6 Konsentrasi Kdd pada tanah mineral pasang surut, baik tanpa maupun dengan aplikasi kompos dari berbagai bahan organik lokal yang dikombinasikan. Garis di atas batang menunjukkan simpangan baku $(n=5)$. Huruf yang sama di atas garis pada setiap perlakuan menunjukkan tidak berbeda nyata berdasarkan BNJ taraf $\alpha=5 \%$. Kontrol = tanpa kompos dan komplementer; JKD = kombinasi kompos jerami $4 \mathrm{t} \mathrm{ha}^{-1}$ dan dekanter padat $2 \mathrm{t}$ ha ${ }^{1}$; JKR = kombinasi kompos jerami $4 \mathrm{t} \mathrm{ha}^{-1}$ dan limbah padat karet remah $2 \mathrm{t}$ ha-1; SKD = kombinasi kompos TKKS $4 \mathrm{t} \mathrm{ha}^{-1}$ dan dekanter padat $2 \mathrm{t} \mathrm{ha}^{-1}$; SKR $=$ kombinasi kompos TKKS $4 \mathrm{t} \mathrm{ha}^{-1}$ dan limbah padat karet remah $2 \mathrm{t}$ ha 1; PKD = kombinasi kompos purun tikus $4 \mathrm{t} \mathrm{ha}^{-1}$ dan dekanter padat $2 \mathrm{t} \mathrm{ha-1}$; $\mathrm{PKR}=$ kombinasi kompos purun tikus $4 \mathrm{t} \mathrm{ha}^{-1}$ dan limbah padat karet remah $2 \mathrm{t} \mathrm{ha}^{-1}$. 


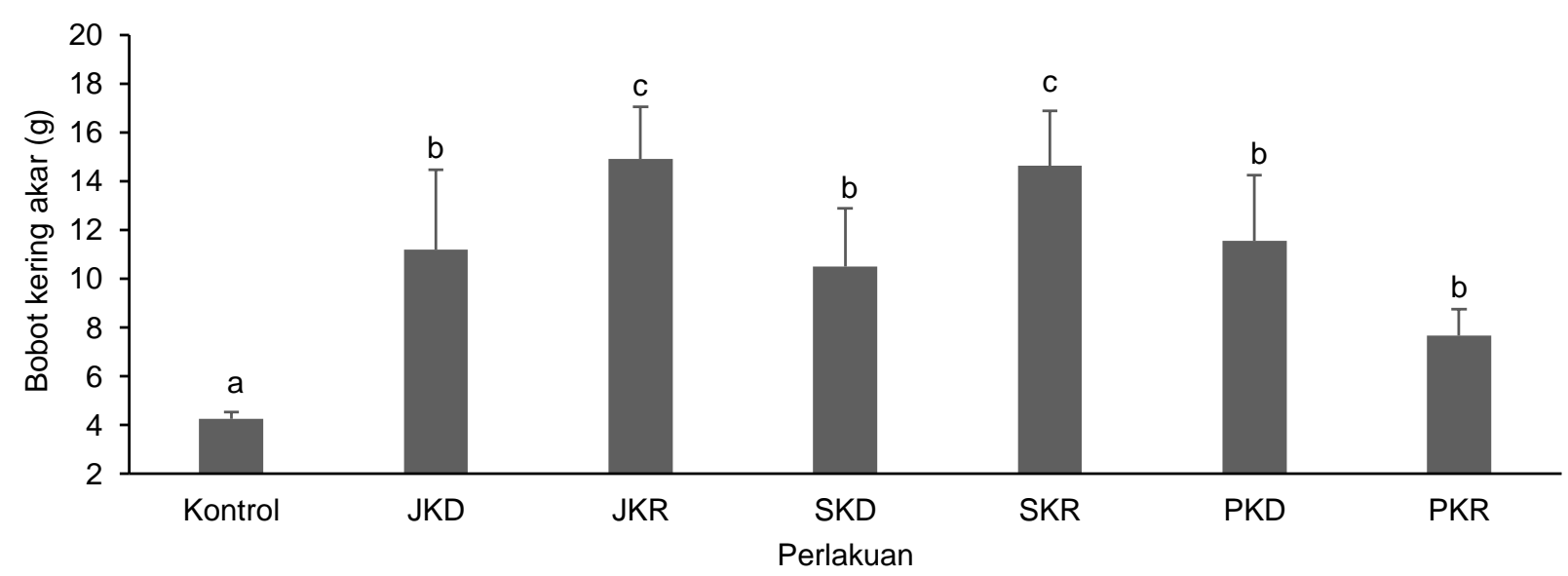

Gambar 7 Bobot kering akar tanaman Padi yang ditanam pada tanah mineral pasang surut, baik tanpa maupun dengan aplikasi kompos dari berbagai bahan organik lokal yang dikombinasikan. Garis di atas batang menunjukkan simpangan baku $(\mathrm{n}=5)$. Huruf yang sama di atas garis pada setiap perlakuan menunjukkan tidak berbeda nyata berdasarkan BNJ taraf $\alpha=5 \%$. Kontrol = tanpa kompos dan komplementer; JKD = kombinasi kompos jerami $4 \mathrm{t}$

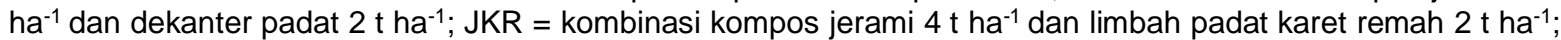

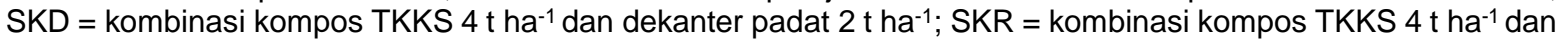

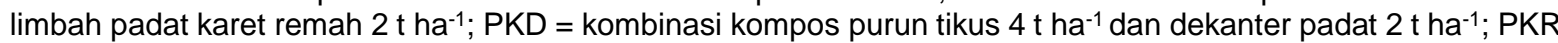
$=$ kombinasi kompos purun tikus $4 \mathrm{t} \mathrm{ha}^{-1}$ dan limbah padat karet remah $2 \mathrm{t} \mathrm{ha}^{-1}$.

Pada perlakuan kontrol dihasilkan rerata bobot kering akar yang sangat rendah, diduga akibat cekaman logam Fe dan Al serta ketersediaan unsur hara yang rendah, sedangkan aplikasi kombinasi kompos jerami dan LPKR maupun kombinasi kompos TKKS dan LPKR lebih mampu menyediakan unsur hara dan mendorong pengkelatan Fe dan Al. Sopandie (2013) menjelaskan bahwa cekaman $\mathrm{Fe}$ dan Al berdampak buruk bagi perakaran tanaman; akar tidak dapat berkembang maksimal apalagi yang dibudidayakan pada tanah yang miskin unsur hara. Perkembangan akar bersifat linear terhadap pertumbuhan jaringan tanaman yang ada di atasnya. Semakin tinggi indeks bobot kering akar, semakin tinggi metabolisme yang terjadi; artinya, terjadi optimaliasi serapan hara dan unsur lainnya sehingga fotosintat dapat dibagikan ke seluruh jaringan tanaman. Akar berperan penting dalam menyerap hara dan menyimpan asimilatnya serta mengembangkannya menjadi jaringan baru. Morfofisiologis akar berbeda-beda terutama jika dalam fase hidupnya mengalami cekaman biotik maupun abiotik (Phule et al. 2019; Karlova et al. 2021).

Relatif tingginya bobot kering akar pada semua perlakuan kecuali abiotik disebabkan oleh aplikasi kompos dan bahan komplementer yang membuat cekaman abiotik dapat diminimalkan serta lebih tersedianya hara pada perlakuan tersebut. Penggunaan VUB juga berperan meningkatkan biomassa tanaman. Penggunaan Inpara-3 yang diberi perlakuan kompos dan bahan komplementer dapat bertahan dalam kondisi cekaman abiotik yang relatif ekstrem. Diduga, mekanisme yang terjadi adalah toleransi; sebagaimana terlihat dari pertumbuhan fisik akar dan organ tanaman lainnya yang relatif bagus selama kegiatan penelitian. Dalam kondisi tercekam, ada 3 kategori respons tanaman, yakni escape/susceptible, avoidance, dan tolerance (Rao 2006) dengan berbagai tanda dan karakter khusus. Ketahanan tanaman ini dapat terindikasi dari bobot kering akar yang langsung berinteraksi dengan cekaman abiotik. Pertumbuhan, perkembangan, dan produksi VUB dapat dioptimalkan dengan membenahi sifat kimia dan fisik tanah untuk meminimalkan cekaman abiotik. Abdillah et al. (2020) melaporkan bahwa bobot kering akar padi Inpara-3 yang ditanam pada tanah gambut dan tanah mineral pasang surut meningkat dibandingkan perlakuan kontrol, akibat aplikasi abu batu bara yang mampu membenahi tanah. Ada asumsi di kalangan petani lokal bahwa penggunaan VUB harus dengan perawatan dan aplikasi pupuk sintetik yang intensif (Hidayat et al. 2010). Penelitian ini membuktikan bahwa penggunaan VUB pada tanah mineral dari rawa pasang surut tidak sertamerta harus mengintensifkan pemupukan kimia sintetik melainkan dapat mengoptimalkan bahan organik lokal yang potensial di daerah tersebut. Khairullah (2016) menjelaskan bahwa pemilihan varietas padi yang tepat untuk dibudidayakan di lahan pasang surut dan aplikasi pembenah tanah yang tepat menjadi kunci keberhasilan praktik budi daya padi. Pengaruh aplikasi pupuk sintetik hanya dapat terlihat melalui sifat tanah yang telah diperbaiki untuk mengurangi larutnya logam dan kemasaman tanah (Koesrini et al. 2021; Masganti et al. 2019).

\section{Bobot Gabah Kering Giling (GKG)}

Hasil tanaman padi yang dapat dikonsumsi adalah beras yang berasal dari GKG. Kapabilitas tanaman padi memproduksi GKG menentukan suksesi budi daya tanaman padi yang berfotosintesis secara optimal menghasilkan karbohidrat $\left(\mathrm{C}_{6} \mathrm{H}_{12} \mathrm{O}_{6}\right)$. Gambar 8 menunjukkan peningkatan nyata bobot GKG dari perlakuan aplikasi kombinasi kompos dan dekanter padat maupun LPKR dibandingkan perlakuan kontrol. Kombinasi kompos jerami dan LPKR (JKR) mem- 


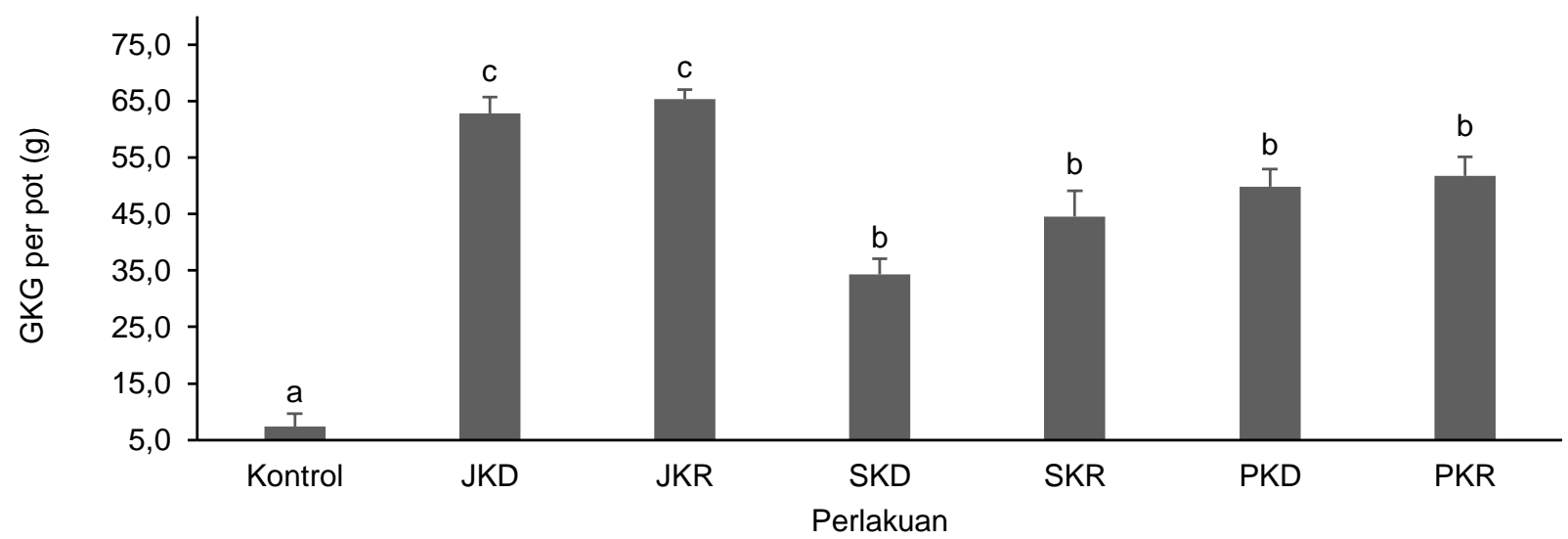

Gambar 8 Bobot gabah kering giling (GKG) dari tanaman padi yang ditanam pada tanah mineral pasang surut, baik tanpa maupun dengan aplikasi kompos dari berbagai bahan organik lokal yang dikombinasikan. Garis di atas batang menunjukkan simpangan baku $(\mathrm{n}=5)$. Huruf yang sama di atas garis pada setiap perlakuan menunjukkan tidak berbeda nyata berdasarkan BNJ taraf $\alpha=5 \%$. Kontrol = tanpa kompos dan komplementer; JKD = kombinasi kompos jerami $4 \mathrm{t}$ ha-1 dan dekanter padat $2 \mathrm{t} \mathrm{ha}^{-1}$; JKR $=$ kombinasi kompos jerami $4 \mathrm{t} \mathrm{ha} \mathrm{h}^{-1}$ dan limbah padat karet remah $2 \mathrm{t} \mathrm{ha}^{-1}$; SKD $=$ kombinasi kompos TKKS $4 \mathrm{t} \mathrm{ha}^{-1}$ dan dekanter padat $2 \mathrm{t} \mathrm{ha-1}$; SKR $=$ kombinasi kompos TKKS $4 \mathrm{t} \mathrm{ha}^{-1}$ dan limbah padat karet remah $2 \mathrm{t}$ ha $^{-1}$; PKD = kombinasi kompos purun tikus $4 \mathrm{t} \mathrm{ha} \mathrm{A}^{-1}$ dan dekanter padat $2 \mathrm{t} \mathrm{ha}^{-1}$; PKR = kombinasi kompos purun tikus $4 \mathrm{t} \mathrm{ha}^{-1}$ dan limbah padat karet remah $2 \mathrm{t} \mathrm{ha}^{-1}$.

berikan bobot GLG tertinggi (66,3 g) yang berbeda nyata dibandingkan perlakuan lainnya tetapi tidak berberbeda nyata dibandingkan kombinasi kompos jerami dan dekanter padat (JKD), yakni 64,5 g. Adapun GLG terendah ialah pada perlakuan kontrol, yang hanya $7,2 \mathrm{~g}$. Tambahan dekanter padat pada perlakuan kombinasi kompos mampu mendorong terakumulasinya nutrisi untuk tanaman sebagaimana yang dilaporkan (Embrandiri et al. 2016) dan aplikasi LPKR pada tanah mampu menyediakan unsur hara (Abdillah \& Aldi 2020).

Pembentukan karbohidrat dalam bentuk gabah melibatkan banyak proses metabolisme dan memerlukan unsur hara makro maupun mikro. Pembentukan gabah setidaknya memerlukan unsur hara utama seperti nitrogen, fosforus, dan magnesium dalam jumlah yang spesifik dalam proses metabolismenya. Pada penelitan ini, aplikasi berbagai berbahan kompos dengan kombinasinya berpengaruh meningkatkan bobot GKG dengan cara menyediakan secara optimal keperluan tanaman untuk bermetabolisme dan berfotosintesis. Rajiman (2020) menegaskan bahwa nitrogen dibutuhkan sesuai dengan fasenya untuk pembentukan protein dan asam nukleat dalam kegiatan fotosintesis. Fosforus yang diserap tanaman berfungsi dalam penyusunan inti sel, menaikkan persentase pembentukan gabah padi, sementara magnesium berfungsi mengaktifkan enzim untuk metabolisme dan penyusun rantai dalam klorofil. Jika $\mathrm{P}$ dan $\mathrm{Mg}$ telah terjerap membentuk kompleks ikatan logam, produksi tanaman akan sangat rendah. Hal ini yang mungkin terjadi pada hasil padi dengan perlakuan kontrol yang hasilnya sangat rendah. Secara fisiologis hubungan sinks dan sources dalam tanaman juga menentukan potensi hasil. Varietas padi yang memiliki sinks tinggi tetapi source rendah mengakibatkan sinks tersebut tidak termanfaatkan secara optimal dan pada akhirnya persentase produksi sangat rendah (Burnett
2019). Faktor lain juga mendukung antara lain air yang mengandung konsentrat hara maupun logam yang tidak seimbang, suhu sebagai pengantar metabolisme, dan radiasi sebagai unsur fotosintesis tanaman (Makarim \& Suhartatik 2009).

\section{KESIMPULAN}

Aplikasi kombinasi kompos dari berbagai macam bahan dan limbah dekanter padat maupun LPKR dapat memperbaiki sifat kimia tanah mineral sulfat masam dari lahan pasang surut yang terbukti pada aplikasi perlakuan JKD yang dapat menurunkan konsentrasi $\mathrm{Fe}$ - dan Al-terlarut serta meningkatkan ketersediaan $\mathrm{P}$ dan K. Perlakuan SKD mampu meningkatan $\mathrm{pH}$ dan total $\mathrm{N}$-mineral tanah. Aplikasi JKR memberikan hasil optimal pada hasil bobot kering akar dan hasil bobot GKG.

\section{UCAPAN TERIMA KASIH}

Penulis mengucapkan terima kasih atas hibah Penelitian Dosen Pemula dari Direktorat Riset dan Pengabdian Masyarakat Kementerian Pendidikan, Kebudayaan, Riset, dan Teknologi Republik Indonesia, melalui Lembaga Layanan Pendidikan Tinggi wilayah XI Kalimantan dengan Nomor Kontrak 072/E4. 1.AK.04.PT/2021. Penghargaan yang tinggi juga kepada unit Penelitian dan Pengabdian Masyarakat Politeknik Hasnur sehingga penelitian ini dapat terlaksana

\section{DAFTAR PUSTAKA}

Abdillah MH. 2021. Pengomposan tandan kosong 
kelapa sawit menggunakan berbagai efektif mikroorganisme lokal. Agrotechno: Jurnal IImiah Teknologi Pertanian. 6(1): 17-24. https://doi.org/https://doi.org/10.24843/JITPA.2021. v06.i01.p03

Abdillah MH, Aldi M. 2020. Aplikasi limbah padat karet remah pada tanah podsolik merah kuning terhadap ketersediaan hara makro dan perbaikan sifat fisika tanah. EnviroScienteae. 16(2): 264-275. https://doi.org/10.20527/es.v16i2.9658

Abdillah MH, Effendi NR, Rusnandar N. 2020. Karakteristik fisik dan kimia limbah padat industri karet remah dengan masa inkubasi berbeda. $\begin{array}{lll}\text { Agrisains. } & 6(1) \text { : }\end{array}$ https://doi.org/10.46365/agrs.v6i01.377

Abdillah MH, Saidy AR, Wahdah R. 2020. Pertumbuhan dan produksi padi varietas Inpara-3 pada tanah tergenang yang diberikan abu batubara. Rawa Sains. 10(1): 772-779. https://doi.org/10.36589/rs.v10i1.108

Al-jabri M. 2013. Teknologi uji tanah untuk penyusunan rekomendasi pemupukan berimbang tanaman padi sawah. Pengembang Inovasi Pertanian. 6(1): 1122.

Andayani S, Hayat ES. 2019. Pengayaan kompos tandan kosong kelapa sawit dengan lumpur laut dan biochar sekam padi pada tanaman padi di tanah sulfat masam. Agritech. 21(1): 45-54.

Anggria L, Rustaman T, Kasno A. 2014. Nitrogen dynamic from applied rice straw compost in flooded soil. Jurnal Tanah dan Iklim. 36(2): 89-94.

Annisa W, Hanudin E. 2013. Peran ligan organik terhadap pembentukan oksida besi di tanah sulfat masam. Jurnal Sumberdaya Lahan, 7(1): 37-46. https://doi.org/10.2018/jsdl.v7i1.6428

Annisa W, Purwanto BH, Shiddieq D. 2011. Pemberian jerami padi dan purun tikus pada berbagai tingkat dekomposisi terhadap konsentrasi besi dalam tanah dan serapan besi oleh padi di tanah sulfat masam. Jurnal Tanah dan Iklim. 12(edisi khusus): 26-29.

Annisa W, Subagio H. 2016. Analisis profil pengaruh bahan organik terhadap konsentrasi besi ferro dan serapannya di lahan rawa pasang surut. Jurnal Informatika Pertanian. 25(2): 241-248.

Asikin S, Thamrin M. 2012. Manfaat purun tikus (Eleocharis dulcis) pada ekosistem sawah rawa. Jurnal Litbang Pertanian. 31(1): 35-42.

Barus J. 2011. Uji efektivitas kompos jerami dan pupuk NPK terhadap hasil padi. Jurnal Agrivivor. 10(3): 247-252.

BPS. 2021. Luas panen, produksi, dan produktivitas padi menurut provinsi 2018-2021. [internet]. [diakses 12 September 2021] tersedia pada https://www.bps.go.id/indicator/53/1498/1/luaspanen-produksi-dan-produktivitas-padi-menurutprovinsi.html.

Burnett AC. 2019. Source - sink relationships. In eLS (pp. 31-42). (John Wiley \& Sons) Ltd Chicheher. https://doi.org/10.1002/9780470015902.a0001304. pub2

Cahya P. 2021. Pengaruh pemberian kotoran ayam dan kompos tandan kosong kelapa sawit terhadap besi larut dan aluminium dapat tukar pada lahan pasang surut. [Skripsi]. Banjarbaru (ID): Lambung Mangkurat University.

Druchok M, Holovko M, Bryk T. 2004. A molecular dynamics study of $\mathrm{Al}^{3+}$ in water: Hydrolysis effects. Condensed Matter Physics. 7(4): 699-707. https://doi.org/10.5488/cmp.7.4.699

Duaja MD, Kartika E, Fransisca DC. 2020. Pemanfaataan limbah padat pabrik kelapa sawit dan pupuk anorganik pada tanaman kailan (Brassica alboglabra) di tanah bekas tambang batubara. $\quad$ Agric. 32(1): 29-38. https://doi.org/10.24246/agric.2020.v32.i1.p29-38

Embrandiri A, Rupani PF, Ismail SA, Singh RP, Ibrahim MH, Kadir MO. 2016. The effect of oil palm decanter cake on the accumulation of nutrients and the stomatal opening of Solanum melongena (brinjal) plants. International Journal of Recycling of Organic Waste in Agriculture. 5(2): 141-147. https://doi.org/10.1007/s40093-016-0124-8

Fahmi A, Radjagukguk B, Purwanto BH. 2009. Kelarutan fosfat dan ferro pada tanah sulfat masam yang diberi bahan organik jerami padi. Journal of Tropical Soils. 14(2): 119-125. https://journal.unila.ac.id/index.php/tropicalsoil/artic le/view/290/309

Hairani A, Susilawati A. 2013. Changes of soil chemical properties during rice straw decomposition in different types of acid sulphate soils. Jounal of Tropical Soil. 18(2): 99-103. https://doi.org/10.5400/jts.2013.18.2.99

Hartatik W, Setyorini D. 2008. Validasi rekomendasi pemupukan NPK dan pupuk organik pada padi sawah. Seminar Nasional dan Dialog Sumberdaya Lahan Pertanian, 275-283.

Hartatik W, Sulaiman, Kasno A. 2006. Perubahan Sifat Kimia Tanah dan Ameliorasi Sawah Bukaan Baru. In Lahan Sawah Bukaan Baru (pp. 53-75). IAARD Press.

Ibrahim Z, Ahmad M, Aziz AA, Ramli R, Hassan K, Alias AH. 2019. Properties of chemically treated oil palm empty fruit bunch (EFB) fibres. Journal of Advanced Research in Fluid Mechanics and Thermal Sciences. 57(1): 57-68.

Ifansyah H, Saidy AR. 2019. Sifat kimia tanah dan pertumbuhan tanaman padi yang dipupuk dengan 
kompos jerami diperkaya azotobacter pada sistem pertanaman SRI dan konvensional. Seminar Nasional Lingkungan Lahan Basah. 4(1): 60-64.

Indriyati LT, Sabiham S, Kadarusman LK, Situmorang R. 2008. Transformasi nitrogen dalam tanah tergenang: Aplikasi jerami padi dan kompos jerami padi. Jurnal Tanah Tropika. 13(3): 189-197.

Kaparang G, Paulus MJ, Walingkas SA. 2017. Pemberian pupuk NPK dan kompos jerami pada pertumbuhan dan hasil padi (Oryza sativa L) metode SRI (System of Rice Intensification). Cocos. 1(6): 17-24.

Karlova R, Boer D, Hayes S, Testerink C. 2021. Root plasticity under abiotic stress. Plant Physiology. 187(3):

https://doi.org/10.1093/plphys/kiab392

Khairullah I. 2016. Urgensi pemilihan varietas untuk meningkatkan produktivitas padi di lahan rawa. Prosiding Seminar Nasional Inovasi Teknologi Pertanian, 244-250.

Koesrini, Nurzakiah S, Mayasari V, Rina Y. 2021. The adaptability of rice varieties on tidal swampland in South Kalimantan. IOP Conference Series: Earth and Environmental Science. 648(1): 1-10. https://doi.org/10.1088/1755-1315/648/1/012027

Koesrini, Sosiawan, H., \& Darsani, Y. R. (2020). Preferensi petani terhadap beberapa varietas padi inpara di lahan rawa pasang surut Kalimantan Selatan. Jurnal Pertanian Agros. 22(1): 41-50. http://e-

journal.janabadra.ac.id/index.php/JA/article/view/1 $108 / 740$

Lubis FZ. 2019. Respon pertumbuhan dan produksi beberapa varietas padi gogo terhadap pemberian berbagai bahan organik. [Skripsi]. Medan (ID): Universitas Sumatera Utara.

Maimunah. 2019. Studi serapan besi (Fe) oleh tanaman jeringau (Acorus calamus) dan purun tikus (Eleocharis dulcis) pada sistem lahan basah buatan air sumur. [Skripsi]. Banjarbaru (ID): Lambung Mangkurat University.

Makarim AK, Suhartatik E. 2009. Morfologi dan Fisiologi Tanaman Padi. In Tanaman Padi (pp. 295330). IAARD Press.

Masganti, Susilawati A, Khairullah I, Anwar K. 2019. Pengendalian keracunan besi untuk peningkatan produktivitas padi di lahan rawa pasang surut bukaan baru. Jurnal Sumberdaya Lahan. 13(2): 103-113.

http://ejurnal.litbang.pertanian.go.id/index.php/jsl/ar ticle/view/11441

Masganti, Nurhayati, Yuliani N. 2017. Peningkatan produktivitas padi di lahan pasang surut dengan pupuk $p$ dan kompos jerami padi. Jurnal Tanah dan Iklim. 41(1): 17-24. https://doi.org/10.2017/jti.v41i1.6058

Mulyani A, Sarwani M. 2013. Karakteristik dan potensi lahan sub-optimal untuk pengembangan pertanian di Indonesia. Jurnal Sumberdaya Lahan. 7(1):4755. https://doi.org/10.2018/jsdl.v7i1.6429

Napisah K, Annisa W. 2019. Peran purun tikus (Eleocharis dulcis) sebagai penyerap dan penetral Fe di lahan rawa pasang surut. Jurnal Sumberdaya Lahan. 13(1): 53-59. https://doi.org/10.21082/jsdl.v13n1.2019.53-59

Phule AS, Barbadikar KM, Madhav MS, Subrahmanyam D, Senguttuvel P, Babu MBBP, Kumar PA. 2019. Studies on root anatomy, morphology and physiology of rice grown under aerobic and anaerobic conditions. Physiology and Molecular Biology of Plants. 25(1): 197-205. https://doi.org/10.1007/s12298-018-0599-z

Putri AD. 2021. Perubahan pH, Fe-larut dan P-tersedia pada lahan pasang surut dengan pemberian bahan organik berbahan baku tandan kosong kelapa sawit. [Skripsi]. Banjarbaru (ID): Lambung Mangkurat University.

Rahmadi AH. 2021. Hubungan fosfor tersedia dengan besi larut, aluminium tukar dan $\mathrm{pH}$ tanah lahan pasang surut. [Skripsi]. Banjarbaru (ID): Lambung Mangkurat University.

Rahman ML, Wong ZJ, Sarjadi MS, Soloi S, Arshad SE, Bidin K, Musta B. 2021. Heavy metals removal from electroplating wastewater by waste fiberbased poly (amidoxime) ligand. Water. 13(9): 39-60. https://doi.org/10.3390/w13091260

Rajiman. (2020). Pengantar pemupukan. In Deepublish press.

Rao KVM. 2006. Introduction Physiology and Molecular of Stress Tolerance in Plants. In Physiology and Molecular of Stress Tolerance in Plants (pp. 1-14).

Razie F, Anas I, Sutandi A, Sugiyanta, Gunarto L. 2013. Efisiensi serapan hara dan hasil padi pada budidaya sri di persawahan pasang surut dengan menggunakan kompos diperkaya. Jurnal Agronomi Indonesia. $\quad 41(2)$ : 89-97. https://doi.org/10.24831/jai.v41i2.7509

Rumanti IA, Koesrini, Sosiawan H, Rina Y. 2020. Uji adaptasi dan seleksi varietas partisipatif terhadap galur-galur padi toleran rendaman dan kekeringan di lahan rawa lebak. Jurnal Agronomi Indonesia. 48(2):

$118-126$. https://doi.org/https://dx.doi.org/10.24831/jai.v48i2. 31652

Runtunuwu E, Syahbuddin H, Ramadhani F. 2012. keragaman waktu tanam tanaman padi di Pulau Kalimantan. Jurnal Agronomi Indonesia. 40(1): 814. https://doi.org/10.24831/jai.v40i1.14949 
Sardans J, Peñuelas J. 2015. Potassium: A neglected nutrient in global change. Global Ecology and Biogeography. 24(3). 261-275. https://doi.org/10.1111/geb.12259

Sari FP, Falah F, Anita SH, Ramadhan KP, Laksana RPB, Fatriasari W, Hermiati E. 2021. Pretreatment of oil palm empty fruit bunch (OPEFB) at benchscale high temperature pressure steam reactor for enhancement of enzymatic saccharification. International Journal of Renewable Energy Development. 10(2): 157-169. https://doi.org/10.14710/ijred.2021.32343

Sarman, Indraswari E, Husni A. 2021. Respons pertumbuhan bibit kelapa sawit (Elaeis guineensis Jacq) terhadap decanter solid pembibitan utama. Jurnal Media Pertanian. 6(1): 14-22. https://doi.org/10.33087/jagro.v6i1.110

Septiana M, Triatmoko E, Khairullah I, Saidy AR. 2019. Mineralisasi nitrogen pada tanah tukungan dengan umur yang berbeda. Proseding Seminar Nasional Lingkungan Lahan Basah. 4(2): 307-310.

Sopandie D. 2013. Fisiologi Adaptasi Tanaman (terhadap Cekaman Abiotik pada Agroekosistem Tropika) (N. Januarini (ed.); pertama). IPB Press.

Sugiyanta, Rumawas F, Chozin MA, Ghulamahdi M. 2008. Studi serapan hara N, P, K, dan potensi hasil lima varietas padi sawah (Oryza sativa L.) pada pemupukan anorganik dan organik. Jurnal Agronomi Indonesia. 36(3): 196-203. https://doi.org/10.24831/jai.v36i3.1377

Suriani M, Mahbub M, Rodinah. 2020. Pengaruh kompos jerami padi terhadap kelarutan ferro $\left(\mathrm{Fe}^{2+}\right)$ dan $\mathrm{pH}$ tanah serta pertumbuhan tanaman padi ciherang di tanah sulfat masam. Jurnal Agroekoteknologi. 3(1): 55-61.

Susilawati A, Fahmi A. 2013. Dinamika besi pada tanah sulfat masam yang ditanami padi. Jurnal Sumberdaya Lahan. 7(2): 67-75.

Susilawati A, Nursyamsi D. 2013. Residu jerami padi untuk meningkatkan produktivitas tanah sulfat masam berkelanjutan. Jurnal Sumberdaya Lahan. 7(1): 27-37. https://doi.org/10.2018/jsdl.v7i1.6425

Suwanda HM, Noor M. (2014). Kebijakan pemanfaatan lahan rawa pasang surut untuk mendukung kedaulatan pangan nasional. Jurnal Sumberdaya Lahan, 12(edisi khusus): 31-40. http://ejurnal.litbang.pertanian.go.id/index.php/jsl/ar ticle/view/6480/5771

Tao HH, Snaddon JL, Slade EM, Henneron L, Caliman JP, Willis KJ. 2018. Application of oil palm empty fruit bunch effects on soil biota and functions: A case study in Sumatra, Indonesia. Agriculture, Ecosystems and Environment. 256(15): 105-113. https://doi.org/10.1016/j.agee.2017.12.012

Torres LAZ, Woiciechowski AL, Tanobe VOA, Filho AZ, de Freitas RA, Noseda MD, Szameitat ES, Faulds C, Coutinho P, Bertrand E, Soccol CR. 2021. Lignin from oil palm empty fruit bunches: Characterization, ciological activities and application in green synthesis of silver nanoparticles. International Journal of Biological Macromolecules. 167(15): 1499-1507. https://doi.org/10.1016/j.jjbiomac.2020.11.104

Winarni M, Yudono $\mathrm{P}$, Indradewa $\mathrm{D}$, Sunarminto $\mathrm{BH}$. 2015. Karakterisasi pola mineralisasi $N$ pupuk organik pada tanah sawah organik. Agri-Tek. 16(1): 93-103.

Zaharah AR, Lim KC. 2000. Oil palm empty fruit bunch as a source of nutrients and soil ameliorant in oil palm plantation. Malaysian Journal of Soil Science. 4(1): 51-66. 